\title{
A new species of Stemonitis (Myxomycetes) from Japan
}

\author{
YUKINORI YAMAMOTO
}

YAMAMOTO, Y. 2000: A new species of Stemonitis (Myxomycetes) from Japan. Karstenia 40: 197-198. Helsinki. ISSN 0453-3402.

A new species, Stemonitis marjana Y. Yamam. (Stemonitaceae, Myxomycetes) from Japan is described and illustrated.

Key words: Japan, myxomycetes, Stemonitis, taxonomy

Yukinori Yamamoto, 1010-53, Ohtsu-ko, Kochi-shi, 781-5102, Japan

In the course of my study on the myxomycete biota of Japan, a form of Stemonitis with curious episporic ornamentation was found in my private herbarium. This specimen was collected in summer on dead wood of Japanese red pine (Pinus densiflora Sieb. \& Zucc.). Though it was collected only once, the spores are peculiar among the genus Stemonitis. For this reason it is proposed as a new taxon.

\section{Stemonitis marjana Y. Yamam., n. sp. - Fig. 1}

Fructificationes sporocarpiorum. Sporocarpia fasciculata, stipitata, fere erecta, $2.1-2.9 \mathrm{~mm}$ alta. Capitulum cylindricum, rubro-brunneum vel atro-brunneum, 0.18-0.25 $\mathrm{mm}$ diam., 1.6$2.2 \mathrm{~mm}$ altum. Stipes fere ater, opacus, usque ad 3/10 sporocarpii. Hypothallus membranaceus, argenteus vel brunneolus, communis ad fasciculum sporocarpiorum. Peridium fugax. Columella continuatio stipitis intra sporangium, usque ad apicem capituli attingens. Capillitium brunneolum luce transmissa, reticulum internum cum 2-4 maculis secus radium et reticulum superficialem cum maculis irregularis angularisque, ca. 20-50 $\mathrm{mm}$ diam. et cum ramulis liberis. Sporae globosae, rubro-brunneae ad atro- brunneae luce reflexa, brunneo-cinereae luce transmissa, irregulariter spinulo-reticulata, 8.8-9.8 um diam. Plasmodium ignotum.

Affine Stemonariae minutae Nann.-Bremek. et Y. Yamam., sed sporocarpis altioris, stipite longiore, capillitio levicum reticulo superficiale et spinulis irregularis differt.

Holotypus: Japonia, Prov. Tosa, Kochi-shi, Ohtsu, Seki, in ligno carioso Pini densiflorae, ca. $33^{\circ} 34^{\prime} \mathrm{N}, 133^{\circ} 37^{\prime} \mathrm{E}, 60 \mathrm{~m}$ alt., 20.VIII.1987 Y. Yamamoto 5887 (TNS).

Fructifications sporocarpous. Sporocarps clustered in a small colony, stipitate, nearly erect, 2.1-2.9 mm tall. Capitulum cylindrical, rounded at both ends, reddish-brown to dark brown, 0.18 $0.25 \mathrm{~mm}$ wide and $1.6-2.2 \mathrm{~mm}$ long. Stalk polished, slightly tapering upwards, nearly black, opaque by transmitted light, sometimes perforated at the very base, $0.5-0.7 \mathrm{~mm}$ tall, i.e. $2 / 10-3 / 10$ of the height of the sporocarp. Hypothallus membranous, silvery or pale brown, common to the colony. Peridium early evanescent, sometimes leaving a collar around the stalk at the base of the capitulum. Columella a continuation of the stalk, nearly black, dark brown by transmitted light, reaching nearly to the apex of the capitulum. Capillitium arising from the all length of the colu- 
mella, of almost evenly thickened and smooth tubules, sometimes with slight membranous enlargements at the axils, pale brown by transmitted light, branched and anastomosed to form an inner net with 2-4 meshes across the radius, and an irregular surface net with angular meshes, (5-) $20-50(-75) \mu \mathrm{m}$ in diam., also with both long and short free ends pointing outwards. Spores globose, reddish-brown to dark brown in mass, brownish-grey by transmitted light, with an irregular rather large-meshed reticulum of flexuous rows of large and small spinules, partly only spinulose, partly with elongated meshes, the number of meshes per hemisphere highly variable, $8.8-9.8 \mu \mathrm{m}$ (mean $=9.4, \mathrm{sd}=0.27, \mathrm{n}=20$ ) in diam. including spinules, the spinules ca. $0.7-0.8 \mu \mathrm{m}$ long. Plasmodium not observed.

Eponymy: In honour of Prof. Marja Härkönen who is especially distinguished in her survey on African myxomycete biota.

Distribution: Known only from the type locality.
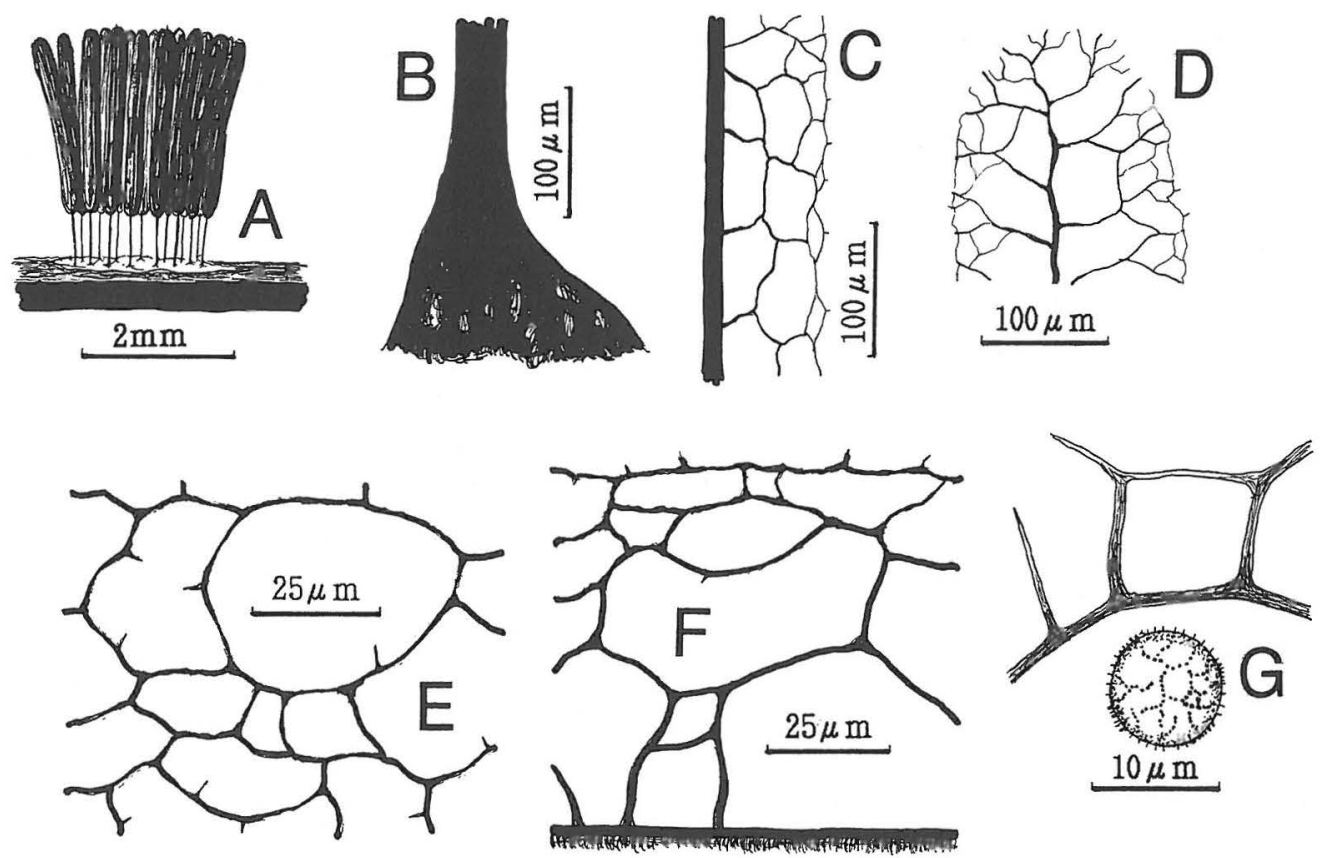

Fig. 1. Stemonitis marjana (holotype). A. A cluster of stipitate sporocarps. B. Basal part of stalk. C. Columella and capillitium. D. Apical part of capitulum after spores are shed. E. Surface net. F. Inner net of capillitium. G. Peripheral capillitium and a spore.
Note: The stalk-base of this new taxon is sometimes perforated as observed in some species of the genus Comatricha, but the clustered sporocarps and the surface net of the capitulum are characteristic of the genus Stemonitis. The spore ornamentation is very much like that of Stemonaria minuta Nann.-Bremek. \& Y. Yamam. (1987) but differs in its larger sporocarp, longer stalk, smooth capillitium, by the presence of a surface net and its episporic spinules of irregular size. It is also somewhat similar to the species with spinulose-reticulate or verruculose-reticulate spores of Stemonitis (e.g. S. fusca Roth), Stemonaria (e.g. S. fuscoides Nann.-Bremek. \& Y. Yamam), Stemonitopsis (e.g. S. reticulata (H. C. Gilbert) Nann.-Bremek. \& Y. Yamam.) and Comatricha (e.g. C. reticulospora Ing \& Holland) but the spore ornamentation is completely different.

\section{References}

Nannenga-Bremekamp, N. E. \& Yamamoto, Y. 1987: Additions to the Myxomycetes of Japan. III. - Proc. K. Ned. Akad. Wet. C. 90: 311-349. 